\title{
CORPORATE SOCIAL RESPONSIBILITY'S PATHWAYS TOWARDS CUSTOMER LOYALTY IN ROMANIAN RETAIL: A PLS-SEM MEDIATION ANALYSIS
}

\author{
Nicolae Nae \\ The Bucharest University of Economic Studies, Bucharest, Romania \\ naenicolae98@gmail.com \\ Simona Cătălina Ștefan \\ The Bucharest University of Economic Studies, Bucharest, Romania \\ simona.stefan@man.ase.ro \\ Cătălina Florentina Albu \\ The Bucharest University of Economic Studies, Bucharest, Romania \\ catalina.albu@man.ase.ro
}

\begin{abstract}
For the time being, many companies around the world attach great importance to corporate social responsibility (CSR) practices and policies. This trend that manifests itself worldwide, is also characteristic for Romania, many companies being regularly active in the CSR field. The motivation of these companies to get involved in social or ecological activities is not only related to the moral or ethical side of business, but also to many benefits that CSR can generate, such as improving the company's image or customer loyalty. The purpose of this paper is to analyze the relationship between CSR and customer loyalty in the Romanian retail sector. Moreover, the effect that CSR has on corporate reputation and the mediating role of reputation on the relationship between CSR and customer loyalty has been studied. In this regard, a questionnaire-based survey was conducted to measure the level of social responsibility and corporate reputation perceived by customers of retail stores in Romania, but also their loyalty to a particular store. The obtained results confirm the existence of a positive relationship between CSR and customer loyalty, but also the partial mediation that the corporate reputation exerts on this relationship.
\end{abstract}

Keywords: corporate social responsibility, corporate reputation, customer loyalty, Romanian retail, sustainable development

\section{INTRODUCTION}

Corporate social responsibility (CSR) is a topic that has been given a lot of interest lately, both in the literature and in practice, due to the effects of business activities on employees, customers, public authorities, partners business, shareholders, local communities and the natural environment (Simionescu, 2018). Moreover 
more and more companies around the world are working to integrate social responsibility practices into their business strategy. The socio-economic context that led to the emergence and development of the concept of corporate social responsibility is represented by the economic development that followed the Second World War. This economic development has made it possible to raise living standards, but has also been accompanied by some negative aspects, such as the general deterioration of the natural environment or the widening of development gaps between countries (Stancu, 2018). Therefore, society has become increasingly sensitive to such issues, and expectations regarding the ethical and moral behavior of companies have increased. The attempts of companies to meet the growing expectations of customers in terms of social or environmental issues were the premises for the emergence of the notion of CSR. Emerged after the end of World War II as a new trend in post-war society, CSR is today a widespread concept, a desideratum for any organization that aims to progress, both economically and socially, in the very aggressive competitive context of the current period (Hristea, 2011).

In Romania, the concept of CSR emerged only in the early 90's, when the market was liberalized and allowed multinational companies to operate in our country. These companies were the ones who introduced the concept by transferring organizational culture and practices from headquarters to the local level (Anca, Aston, Stanciu, \& Rusu, 2011). The implementation of responsible business practices has begun to intensify as result of European Union accession, so that, now, this concept is very well known in the Romanian business environment, especially in the case of corporations.

Retail companies, especially large ones, have understood the importance and usefulness of CSR, by including responsible business practices and policies in their strategy. CSR implementation is also determined by the benefits it implies. In the case of stores, by carrying out social or environmental protection actions, the aim is to influence customers by shaping in their psyche a positive, attractive or even unique image of the store (Pop \& Dabija, 2014). With the help of this image, one of the most important objectives of the management of commercial companies can be fulfilled, namely customer loyalty.

The literature contains many papers dealing with the subject of corporate social responsibility and its implications. This special interest is also manifested in Romania, many specialists, professors, or researchers enriching the specialized literature that deals with the topic of CSR (Anca, Aston, Stanciu, \& Rusu, 2011; lamandi \& Filip, 2008; Mihalache, 2015; Simionescu, 2018; Burlea Șchiopoiu \& Popa, 2013). The positive relationship between CSR and customer loyalty has been addressed in many papers, both internationally (Du, Bhattacharya, \& Sen, 2010; Gurlek, Düzgün, \& Meydan Uygur, 2017; Martinez \& del Bosque, 2013; Pratihari \& Uzma, 2018; Perez \& del Bosque, 2015), and nationally (Moisescu O. I., 2015; Moisescu O. I., 2017). However, the papers studying this relationship in the case of Romanian clients are insufficient and do not cover all areas of activity in which the companies involved in CSR operate. There are 
few research that studies the relationship between CSR and customer loyalty in the field of retail (Pop \& Dabija, 2014). Also, the mediating role of the corporate reputation in the field of retail trade has not been studied so far for the Romanian market, although this model of mediation has been approached in the literature (Gurlek, Düzgün, \& Meydan Uygur, 2017; Pratihari \& Uzma, 2018).

The aim of this paper is to study the influence that CSR determines on customer loyalty and how CSR determines loyalty to a particular store through corporate reputation. To conduct this research, the questionnaire-based survey method was used to measure the level of social responsibility and corporate reputation perceived by customers of retail stores in Romania, but also their loyalty to a particular store.

\section{CSR IN ROMANIAN RETAIL}

CSR can be implemented in any type of organization, in different forms, which require a greater or lesser effort from the company. However, only large companies have the capacity to articulate a coherent CSR strategy to include in the overall business strategy. Also, even if a small firm is actively involved in the field of CSR, its ability to communicate to the public the activities carried out and the measures adopted is reduced, due to insufficient marketing budgets. Therefore, in the field of retail trade, CSR activities and policies are much more visible in the case of large companies, those that have a national network of hypermarkets and supermarkets.

Retail companies are actively involved in the field of CSR, also seeking to obtain advantages. Ramasamy et al. (2010) considers that the increasing importance given to corporate social responsibility in the retail field is mainly due to the desire to improve the company's image and reputation, by adding differentiating elements for the offered products or services. Therefore, the aim is to obtain a competitive advantage by differentiating from competitors' products or services. Given that the cost advantage is increasingly difficult to obtain, as most companies have been concerned about this, the advantage through differentiation is a much more efficient way to place the company in a superior position to competing companies. CSR, through the variety of practices it involves, is a good way for companies to create a unique image. Differentiating from competing companies is very important for retail companies, given that many of the products they sell can be found on the shelves of competitors, at similar prices. Therefore, the creation of an individualized image for a retail company can be achieved rather with the help of the services offered and the policies adopted, in addition to the products marketed. The key to success in the differentiation process is the implementation of those practices that are most desired by customers and society. Therefore, in order to fully benefit from the advantages of CSR, it is necessary for companies to know what their customers' expectations or value system is, in order to meet their needs and expectations. 


\section{CSR DIMENSIONS}

The most popular CSR size segmentation model is that of Archie Carroll. He created a model, called the "pyramid of social responsibility", in which he identifies four types of responsibilities, hierarchically positioned (Carroll, 1991). The four dimensions of CSR identified are: economic responsibilities, legal responsibilities, ethical responsibilities, and discretionary responsibilities. However, for this research, the dimensions identified by Graafland, Eijffinger, \& Smid (2004) were used. These dimensions are called "the three Ps" (Graafland, Eijffinger, \& Smid, 2004):

1. Profit: describes the economic dimension. This dimension refers to the creation of value through the production of goods or the provision of services, and through them jobs and sources of income for the population are generated. The financial profit reflects the consumer's appreciation for the company's products and the efficiency with which the factors of production were used. Profit attainment determines the financial stability of the company, providing the basis for continuing business and involvement in social and environmental issues. Also, the economic dimension includes all the financial obligations that a company has towards its stakeholders: taxes and duties towards the state, salaries and premiums towards employees, payment of invoices to suppliers, etc.

2. People: refers to the social dimension. This dimension concerns a lot of aspects regarding the effects of business on people, but also the involvement in society in order to improve the standard of living and prosperity of local communities. Therefore, measures corresponding to this dimension can be represented by respecting employees' rights, ensuring the safety of employees at work, creating a relaxed working environment, eliminating discriminatory measures, stimulating interpersonal relationships, intervening in society through donations, sponsorships, organizing cultural or sporting events etc.

3. Planet: describes the environmental dimension. CSR must also include elements related to environmental protection. A degraded and polluted environment produces negative effects on the health and quality of life of the population. Therefore, if desired to maximize the well-being of society, care for the natural environment needs to be considered by companies, to reduce its negative impact or to improve the state of the environment.

Between Carroll's (1991) four-dimensional approach and Graafland, Eijffinger, \& Smid's (2004) threedimensional approach, there are both similarities and differences. Both approaches describe the economic dimension as the most important. However, unlike Carroll, who treats the economic dimension from the perspective of shareholders, in the three-dimensional approach, the economic dimension also includes the company's financial obligations to its stakeholders. Although it may seem that these obligations are included in legal responsibilities, in reality, things may differ. Strict observance of the laws 
and regulations in force does not guarantee the ethical and moral character of companies. There are practices that fall within the limits of the law, but which do not pursue the general good, but the company's own interest. If we refer to the economic obligations of a company, they can be violated by unjustifiably postponing the payment to a supplier in difficulty or offering salaries that, although exceed the minimum level established by law, are small compared to the volume of work performed by employees. Also, in contrast with the Carrol's approach, where responsibilities to the environment are only intuited, in the approach of Graafland, Eijffinger, \& Smid (2004) these responsibilities are explicitly specified, facilitating a deeper understanding of the practices in which CSR materializes.

CSR can take many forms, resulting in actions or policies that differ from one organization to another. Pratihari and Uzma (2018) utilize in their paper the four dimensions of CSR delimited by Carroll (1991): economic responsibilities, legal responsibilities, ethical responsibilities, and philanthropic responsibilities. Perez and del Bosque (2015) use in their study the following dimensions: CSR towards society, CSR towards customers and CSR towards employees. In the study of Moisescu and Berács (2015) CSR is described by economic success, community development, sponsorships, responsibilities to customers, employees, the environment, and public authorities. However, the dimensions of corporate social responsibility that will be used in this paper are those delimited by Graafland, Eijffinger, \& Smid (2004) and used by Martinez, Perez, \& del Bosque (2014), Gurlek, Düzgün, \& Meydan Uygur (2017) and Vashchenko (2014), respectively the economic dimension, the social dimension and the environmental dimension.

\section{HYPOTHESES DEVELOPMENT}

\section{CSR and customer loyalty}

Customer loyalty is a complex concept with a wide meaning, the definition of which has been a challenge for specialists, despite an apparent simplicity of this concept (Moisescu O. I., 2017). Determining customer loyalty to a particular store is a difficult process. Studies on this subject have shown that the mere act of buying repeatedly from a single store is not a sufficient indicator to demonstrate customer loyalty (Majumdar, 2005). For example, East et al. (1995) considers that loyalty is indicated by the proportion of expenditure allocated to a particular brand or store. Moreover, Irina and Zalt (2016) appreciate that recurrent acquisition actions must be associated with a favorable attitude of buyers towards the organization. The favorable attitude of the clients can be stimulated with the help of a good image of the organization, and CSR can be a determining factor of the image of the organization. 
The first studies on customer loyalty in the field of trade showed that it is not possible to discuss a loyal relationship with the store. Customers, due to financial, time or transport constraints, limit themselves to shopping at those stores that are accessible to them in terms of the constraints stated above. Therefore, even if a customer will buy most of the time from a certain store, it is not possible to discuss about loyalty, as it is a forced action of circumstances (East, Harris, Willson, \& Lomax, 1995).

Dunn and Wrigley (1984) notices the need to re-evaluate the loyalty to the store, as a result of social changes, the evolution of the retail structure of cities, as well as the development of the retail and distribution sectors. Increasing the number of supermarkets and hypermarkets, but also increasing the power of stores in front of manufacturers have produced important effects on customer loyalty. Dunn and Wrigley observed in the study, the emergence of a new trend among buyers, namely discretionary loyalty. This new orientation involves the free and conscious choice of a preferred store, being less influenced by financial, temporal or transport constraints. Therefore, customers choose their store based on certain factors, such as the price level, the diversity of the product range, product quality, store advertising campaigns, the overall image of a store, the advantage of being in a large store or supermarket, or hypermarket. Customer loyalty is more pronounced for large stores because they tend to charge lower prices and enjoy a more favorable image than small stores (Dunn \& Wrigley, 1984).

Customer loyalty is a key objective for strategic planning and is a basis for developing a sustainable competitive advantage (Majumdar, 2005). Loyal customers are a great advantage for any company. A loyal customer base is a barrier to entry into the sector for potential competitors, allows for special prices, which may be higher than competitors, increases response time to competitors' innovations and creates a protection barrier against dangerous price competition (Aaker D. A., 1996). Customer loyalty will materialize in future sales and, implicitly, in higher profit for any company (Aaker D. A., 1991). Moreover, loyal customers will have a favorable attitude towards the company, behaving like its ambassadors. They will recommend the products or services of the organization and other people, helping to increase the notoriety of that organization. Also, such customers will be willing to pay higher prices and will be less affected by negative advertising directed against the organization to which they are loyal (Du, Bhattacharya, \& Sen, 2010).

In the literature, the relationship between CSR and customer loyalty is treated in many papers (Du, Bhattacharya, \& Sen, 2010; Gurlek, Düzgün, \& Meydan Uygur, 2017; Martinez \& del Bosque, 2013; Moisescu O. I., 2017; Pratihari \& Uzma, 2018; Perez \& del Bosque, 2015). Du and Bhattacharya (2010, p.9) considers that an organization that is a good corporate citizen can positively influence the level of customer loyalty, "turning them into ambassadors of the company or the brand".

\section{H1: CSR positively influences customer loyalty.}




\section{CSR and corporate reputation}

Corporate reputation is one of the most valuable intangible assets an organization can hold. Both scientific and managerial interest in corporate reputation have grown steadily in recent years, proving the importance of this aspect. In the literature there are numerous papers that attest to the existence of a positive relationship between CSR and corporate reputation (Helm, 2007; Irina \& Zaiț, 2016; Tsoutsoura, 2004; Pratihari \& Uzma, 2018). Bhattacharya and Sen (2004) considers that the attitude of customers is more favorable towards companies involved in the field of CSR.

Corporate reputation is defined by Gardberg and Fombrun (2002, p. 304) as "a collective representation of a firm's past actions and results that describes the firm's ability to deliver valued outcome to multiple stakeholders". The combination of economic and social actions that a company carries out in its relations with its stakeholders is captured in the corporate reputation, which is often interpreted as a competitive advantage and an important intangible asset of any company (Helm, 2007).

Corporate reputation is determined by various aspects, such as the quality of products sold or services provided, innovative activity, the value of investments, the quality of management or the adoption of CSR policies and practices (Du, Bhattacharya, \& Sen, 2010). Because of this multidimensional nature, measuring an organization's reputation is a difficult process. An easy-to-understand evaluation method for the general public is the "Most Admired American Organizations" survey conducted each year by Fortune magazine. The evaluation system of this survey takes into account seven characteristics, one of which is the social and environmental responsibility of the organization (Irina \& Zaiț, 2016).

Until the present, no consensus has been reached on the main meaning and basic elements of the corporate reputation. However, the importance and the multitude of positive effects that are associated with a favorable reputation cannot be denied. For example, it is expected that in the case of reputable companies, their customers will be more loyal and less sensitive to price changes, investors will be able to offer capital more easily, and people who are professionally prepared will wish to work for such organizations (Irina \& Zait, 2016).

Promoting CSR practices and policies will have a positive impact on the company's corporate reputation. The active involvement of companies in the field of CSR will determine the stakeholders to have a positive perception on them, because it highlights certain characteristics. For example, companies that practice CSR actions show financial stability, as they can afford to bear the costs of the actions themselves, but also those related to their communication. Also, such companies prove the adoption of a sustainable business strategy by integrating CSR into the overall business strategy. The orientation of a company towards CSR may suggest a higher quality level of management, as its vision is broader, establishing social objectives, in addition to economic ones. 
H2: CSR positively influences the organization's reputation.

\section{The mediating role of the corporate reputation on the relationship CSR - customer loyalty}

Corporate social responsibility is a desirable practice for both the company and its stakeholders. Implementing a CSR policy can bring many benefits to all parties involved. However, in order for the beneficial effects to be reflected on the company that implements such policies, it is necessary that the effective measures adopted, the actions carried out, the causes and the values promoted be made known to as many people as possible. The extent to which a company's CSR initiatives will lead to favorable results depends on a number of factors, such as the organization's overall marketing strategy and its positioning on CSR policies (Bhattacharya \& Sen, 2004). In this regard it is necessary to express the vision of Matten and Moon (2008, p.405), which define CSR as a series of "clearly articulated and communicated policies and practices of corporations that reflect business responsibility for some of the wider societal good". From this definition it can be observed the need to communicate CSR policies, so that they can be perceived by the public. Communication is an important element of CSR, which ensures transparency towards stakeholders, but it should not be seen only from the perspective of public relations and the related marketing benefits (Hristea, 2011).

Also, the impact of CSR activities on stakeholders is influenced by how they perceive such initiatives (Bhattacharya, Korschun, \& Sen, 2009). In some studies from the literature (Moisescu \& Berács, 2015), when studying the relationship between CSR and loyalty, the phrase "perceived CSR" is used, which emphasizes the idea that it is not the actual social responsibility action that can determine customer loyalty, but how they perceive such actions. Any approach of an organization must be correctly understood by customers, otherwise there is a risk that actions worthy of praise will be perceived negatively by customers. As an example, we can consider the case of cause - related marketing, when a company donates a sum of money for a social cause, this amount coming from the sale of a certain range of products and being directly proportional to the level of sales of those products. Customers may consider that such a corporate social initiative is carried out to raise public awareness, in order to increase sales for those products that are part of the campaign. However, the real purpose is not a commercial one, but a humanitarian one. Therefore, it is important how to communicate with customers, so that their perception is favorable to the organization. CSR will be properly perceived by the public only to the extent that the process of creating value for society and the environment is transparent. One method to improve CSR transparency is to use benchmarking analysis, through an independent company. The result of this analysis is materialized in a report, the publication of which can positively influence the corporate reputation, offering a competitive advantage to companies that promote social and ecological values (Graafland, Eijffinger, \& Smid, 2004). Du and 
Bhattacharya (2010) considers the communication of CSR activities to be a sensitive issue, and the great challenge associated with this communication is to minimize stakeholder skepticism about why responsible business practices are implemented. Once an organization manages to make customers aware of the CSR activities they carry out, it is imperative that managers understand in depth the key issues related to communicating social responsibility. These issues include questions about what needs to be communicated (message content), where the message needs to be conveyed, as well as an understanding of the specific factors for both the company and stakeholders that influence the effectiveness of CSR communication (Du, Bhattacharya, \& Sen, 2010).

Therefore, in order for the positive effects that CSR can generate to be maximum, it is necessary for the company to know the responsible actions carried out by the company. By communicating and promoting CSR-related actions in the public space, it will be possible to achieve an improvement in the image and reputation of the organization.

Reputation enhances the positive results of organizations, as customers will have a more favorable attitude towards companies with a good image (Bhattacharya \& Sen, 2004). A favorable perception of an organization will also translate into a high level of its reputation and, as Dunn and Wrigley (1984) pointed out, customer loyalty is more pronounced in the case of stores with a positive image. Moreover, corporate reputation helps companies to build, sustain, and foster long-term relationships with customers and ultimately have positive effects on its efforts to achieve superior competitiveness and economic performance (Bălan \& Burlea-Șchiopoiu, 2017).

H3: Corporate reputation positively influences customer loyalty.

Therefore, the influence of CSR on customer loyalty can only be maximized to the extent that responsible business practices and social or environmental actions are made known to as many people as possible. However, gaining a good corporate reputation is not an end in itself, the goal being to reap the benefits it can generate. Because corporate reputation positively influences customer loyalty (Helm, 2007; Irina \& Zait, 2016; Tsoutsoura, 2004; Pratihari \& Uzma, 2018), it can be stated that the promotion of CSR actions and policies, by improving the corporate reputation, will positively influence customer loyalty. Therefore, the corporate reputation has the role of mediator in the relationship between CSR and customer loyalty. This model of mediation is found in the literature (Gurlek, Düzgün, \& Meydan Uygur, 2017; Pratihari \& Uzma, 2018). Therefore, on the basis of the above information, the following hypothesis can be established:

H4: Corporate reputation mediates the relationship between CSR and customer loyalty. 


\section{MATERIAL AND METHODS}

\section{Sample and data collection}

The main purpose of this research is to analyze the relationship between CSR and the degree of loyalty of customers in the field of retail, under the mediating effect of corporate reputation. To collect data, we used the survey method based on a questionnaire, conducted among customers of large chain stores in Romania. The questionnaire was distributed in online environment.

The questionnaire was addressed, in an online format, to customers of hypermarket and supermarket chains, using a convenience sampling method. In order for the analyzed answers to come from respondents who are part of the researched population, a filter question was included in the questionnaire. Between May 20 and June 1, 304 people answered the questionnaire, 65\% (198 people) of them being female and 35\% (106 people) male. In terms of residence environment, 89\% (270 people) live in urban areas and 11\% (34 respondents) live in rural areas. Out of the total respondents, $48.4 \%$ are graduates of high school studies, $32.2 \%$ of university studies, $15.1 \%$ of postgraduate studies, $3 \%$ of gymnasium studies and $1.3 \%$ of doctoral studies. All respondents stated that they are customers of the stores included in this study.

\section{Measures}

The questionnaire was divided into three sections. The first section includes the demographic characteristics of the respondents: sex, age, level of education, environment of residence. The second part aimed to determine the level of knowledge and the importance that respondents attach to corporate social responsibility. The last section measured respondents' perceptions of CSR, corporate reputation, and loyalty to a particular store. To measure the corporate social responsibility perceived by customers, the store's reputation, and loyalty, we used items adapted from existing scales, measured on a Likert scale with 5 answer options, where 1 represents total disagreement and 5 total agreement. 15 items were used for CSR measurement (Gurlek, Düzgün, \& Meydan Uygur, 2017; Moisescu O. I., 2015), five for each of its three CSR dimensions, namely economic, social and environmental, seven items for reputation (Gardberg \& Fombrun, 2002; Helm, 2007), and eight for customer loyalty (Irina \& Zait, 2016; Martinez, Perez, \& del Bosque, 2014).

\section{Data analysis}

To evaluate the relationships between CSR, customer loyalty, and corporate reputation, as well as for testing the research hypotheses, the PLS-SEM procedure was selected. The model included five first-order constructs, operationalizing the concepts of corporate reputation (Rep), customer loyalty (Loi) and the three dimension of CSR (economic dimension - CSReco, social dimension - CSRsoc and environmental dimension - CSRenv). As CSR was considered a multidimensional concept, it was operationalized as a reflective-reflective second-order construct, using the repeated indicator approach (Wold, 1982; Hair, 
Sarstedt, Ringle, \& Guderga, 2018). The structural model also included the path between the second-order latent construct of CSR, corporate reputation, and customer loyalty, as they were predicted by the research hypotheses.

SmartPLS 3.3.2 application (Ringle, Wende, \& Becker, 2015) was employed to evaluate the PLS-SEM model and test the proposed hypotheses.

\section{RESULTS}

\section{Descriptive statistics}

To study the relationship between CSR, customer loyalty and corporate reputation, as well as the mediating role (Hair, Sarstedt, Ringle, \& Guderga, 2018) that corporate reputation has on the relationship between CSR and customer loyalty, first, it must be establish the existence of a correlation between all variables included in the model. The correlation coefficients are presented in table 1.

TABLE 1. DESCRIPTIVE STATISTICS

\begin{tabular}{|c|c|c|c|c|c|}
\hline \multirow[b]{2}{*}{ Variables } & \multirow[b]{2}{*}{$M$} & \multirow[b]{2}{*}{$S D$} & \multirow[b]{2}{*}{$\begin{array}{c}\text { Cronbach's } \\
\text { Alpha }\end{array}$} & \multicolumn{2}{|c|}{ Pearson correlation coefficients $(\mathrm{r})$} \\
\hline & & & & $\begin{array}{l}\text { Corporate } \\
\text { reputation }\end{array}$ & $\begin{array}{l}\text { Customer } \\
\text { loyalty }\end{array}$ \\
\hline Total CSR & 2.939 & 0.949 & 0.948 & $0.657^{* * *}$ & $0.603^{* * *}$ \\
\hline Economic CSR & 3.192 & 0.945 & 0.866 & $0.599^{* * *}$ & $0.539^{\star \star *}$ \\
\hline Social CSR & 2.888 & 1.081 & 0.925 & $0.623^{* * *}$ & $0.561^{* \star *}$ \\
\hline Environmental CSR & 2.737 & 1.126 & 0.900 & $0.560^{\star * *}$ & $0.534^{\star \star *}$ \\
\hline Corporate reputation & 3.579 & 0.929 & 0.930 & - & $0.762^{* * *}$ \\
\hline Customer loyalty & 3.398 & 1.069 & 0.951 & $0.762^{\star * *}$ & - \\
\hline
\end{tabular}

$M=$ mean. $S D=$ standard deviation. ${ }^{* * *} p<0.001$. Source: Authors with IBM SPSS Statistics (IBM Corp., 2019)

Following the analysis of the data in table 1 it can be observed that among all variables there are statistically significant correlation coefficients $(p<0.001)$, high intensity ( $r$ in the range $0.5-0.7)$ or very high $(r$ in the range $0.7-0.9$ ). Also, the values of the correlation coefficients do not exceed 0.9 in the case of the relationships between total, economic, social, or environmental CSR and corporate reputation. Otherwise, if the correlation coefficient had been higher than 0.9 , the corporate reputation would have fully explained the customer loyalty variation.

From the data presented in the table it can be seen that each dimension of CSR contributes in different proportions to the formation of the perception of the total perceived social responsibility. The economic dimension registers the highest average, respectively $(M=3.192, S D=0.945)$. This dimension has the greatest influence, as it is the fundamental responsibility of any company (Carroll, 1991; Graafland, Eijffinger, \& Smid, 2004). Starting from the approach of Graafland, Eijfinger, \& Smid (2004), the items contained in the questionnaire corresponding to the economic dimension included issues related to the legal 
Nae, N., Ștefan, S.C., Albu, C.F.

CORPORATE SOCIAL RESPONSIBILITY'S PATHWAYS TOWARDS CUSTOMER LOYALTY IN ROMANIAN RETAIL:

A PLS-SEM MEDIATION ANALYSIS

and ethical dimension of business, including some of the moral obligations of companies. Therefore, customers' expectations regarding this dimension are more accentuated, as they are concerned about the moral character of the business. Some of the aspects included in the economic dimension, such as the full and timely payment of financial obligations to the state, are mandatory practices whose compliance is required by society. Instead, the social and environmental dimensions are discretionary practices, the implementation of which is not imperatively required by society, so the attention paid to them is lower. This may explain the lower level of perception of the two dimensions, $M=2.888, S D=1.081$ for social CSR and $M=2.737, S D=1.126$ for environmental $\mathrm{CSR}$, although all the companies analyzed in this research are actively involved in actions corresponding to these dimensions.

The average corresponding to the corporate reputation suggests a high level of customer perception on this issue. The companies that are included in this research are represented by multinational companies, which have considerable financial power. This allows them to conduct marketing campaigns and actions that can positively influence customers' perceptions of the company. The average value of the corporate reputation is $M=3.579, S D=0.929$, which means that the companies included in the study enjoy a positive image among Romanian customers.

Customer loyalty is also of considerable value $(M=3.398, S D=1.069)$, which highlights the tendency of customers of retail companies to be loyal to a particular store.

\section{Assessment of the measurement and structural model}

The model assessment considered a two-stage approach, as recommended by (Ringle, Sarstedt, Mitchell, \& Gudergan, 2018): evaluation of the measurement model and evaluation of the structural model.

The first order and second-order reflective constructs of the measurement models were evaluated in terms of indicator and internal consistency reliability and convergent and discriminant validity. The results of the measurement model assessment revealed that the constructs may be considered reliable and valid, falling within the recommended limits (Ringle, Sarstedt, Mitchell, \& Gudergan, 2018; Hair., Hult, Ringle, \& Sarstedt, 2017; Henseler, Ringle, \& Sarstedt, 2015): standardized loadings $>0.70$, Cronbach's Alpha $>0.70$, composite reliability $\left(\rho_{C}\right)>0.70$, average variance extracted $(\mathrm{AVE})>0.50$ and (excepting CRSsoc CRSenv relationship) HTMT ratio $<0.90$ (see Table 2 and 3 ). 
Nae, N., Ștefan, S.C., Albu, C.F.

CORPORATE SOCIAL RESPONSIBILITY'S PATHWAYS TOWARDS CUSTOMER LOYALTY IN ROMANIAN RETAIL: A PLS-SEM MEDIATION ANALYSIS

TABLE 2. MEASUREMENT MODEL RELIABILITY AND VALIDITY

\begin{tabular}{|c|c|c|c|c|c|c|}
\hline Constructs & Items & Loadings & $\begin{array}{c}\text { Cronbach's } \\
\text { Alpha }\end{array}$ & $\rho_{A}$ & $\rho_{C}$ & AVE \\
\hline \multirow[t]{5}{*}{ Economic CSR (CSReco) } & CSReco1 & 0.798 & 0.867 & 0.868 & 0.904 & 0.652 \\
\hline & CSReco2 & 0.829 & & & & \\
\hline & CSReco3 & 0.786 & & & & \\
\hline & CSReco4 & 0.834 & & & & \\
\hline & CSReco5 & 0.790 & & & & \\
\hline \multirow[t]{5}{*}{ Social CSR (CSRsoc) } & CSRsoc1 & 0.834 & 0.925 & 0.925 & 0.943 & 0.769 \\
\hline & CSRsoc2 & 0.893 & & & & \\
\hline & CSRsoc3 & 0.887 & & & & \\
\hline & CSRsoc4 & 0.892 & & & & \\
\hline & CSRsoc5 & 0.877 & & & & \\
\hline \multirow[t]{5}{*}{ Environmental CSR (CSRenv) } & CSRenv1 & 0.844 & 0.901 & 0.904 & 0.927 & 0.717 \\
\hline & CSRenv2 & 0.866 & & & & \\
\hline & CSRenv3 & 0.867 & & & & \\
\hline & CSRenv4 & 0.883 & & & & \\
\hline & CSRenv5 & 0.769 & & & & \\
\hline Corporate social responsibility (CSR) & CSReco & 0.844 & 0.948 & 0.951 & 0.954 & 0.584 \\
\hline \multirow[t]{2}{*}{ (Second-order construct) } & CSRsoc & 0.941 & & & & \\
\hline & CSRenv & 0.922 & & & & \\
\hline \multirow[t]{7}{*}{ Corporate reputation (Rep) } & Rep1 & 0.815 & 0.931 & 0.934 & 0.944 & 0.706 \\
\hline & Rep2 & 0.810 & & & & \\
\hline & Rep3 & 0.843 & & & & \\
\hline & Rep4 & 0.854 & & & & \\
\hline & Rep5 & 0.840 & & & & \\
\hline & Rep6 & 0.874 & & & & \\
\hline & Rep7 & 0.845 & & & & \\
\hline \multirow[t]{8}{*}{ Customer loyalty (Loi) } & Loi1 & 0.832 & 0.953 & 0.957 & 0.960 & 0.752 \\
\hline & Loi2 & 0.899 & & & & \\
\hline & Loi3 & 0.910 & & & & \\
\hline & Loi4 & 0.914 & & & & \\
\hline & Loi5 & 0.878 & & & & \\
\hline & Loi6 & 0.793 & & & & \\
\hline & Loi7 & 0.848 & & & & \\
\hline & Loi8 & 0.857 & & & & \\
\hline
\end{tabular}

$\rho_{C}=$ composite reliability; AVE = average variance extracted. Source: Authors with SmartPls (v3.3.2)

(Ringle, Wende, \& Becker, 2015) 
Nae, N., Ștefan, S.C., Albu, C.F.

CORPORATE SOCIAL RESPONSIBILITY'S PATHWAYS TOWARDS CUSTOMER LOYALTY IN ROMANIAN RETAIL:

A PLS-SEM MEDIATION ANALYSIS

TABLE 3. DISCRIMINAT VALIDITY - HTMT RATIO

\begin{tabular}{ccccccc}
\hline & CSR & CSReco & CSRenv & CSRsoc & Loi & Rep \\
\hline CSR & & & & & & \\
CSReco & & & & & & \\
CSRenv & & 0.726 & & & & \\
CSRsoc & & 0.762 & 0.915 & & & \\
Loi & 0.639 & 0.598 & 0.579 & 0.601 & & \\
Rep & 0.700 & 0.669 & 0.609 & 0.669 & 0.812 & \\
\hline
\end{tabular}

Source: Authors with SmartPls (v3.3.2) (Ringle, Wende, \& Becker, 2015)

Given that the results of the first stage proved that the measurement model is accurate and valid, in the second stage the structural model was evaluated, taking into account (Ringle, Sarstedt, Mitchell, \& Gudergan, 2018; Hair., Hult, Ringle, \& Sarstedt, 2017; Chin, 1998): collinearity diagnostic, model's in-sample predictive power (in terms of $R^{2}$ and $f^{2}$ values) and the path coefficients relevance and significance (by bootstrapping technique). The structural model is presented in figure 1.

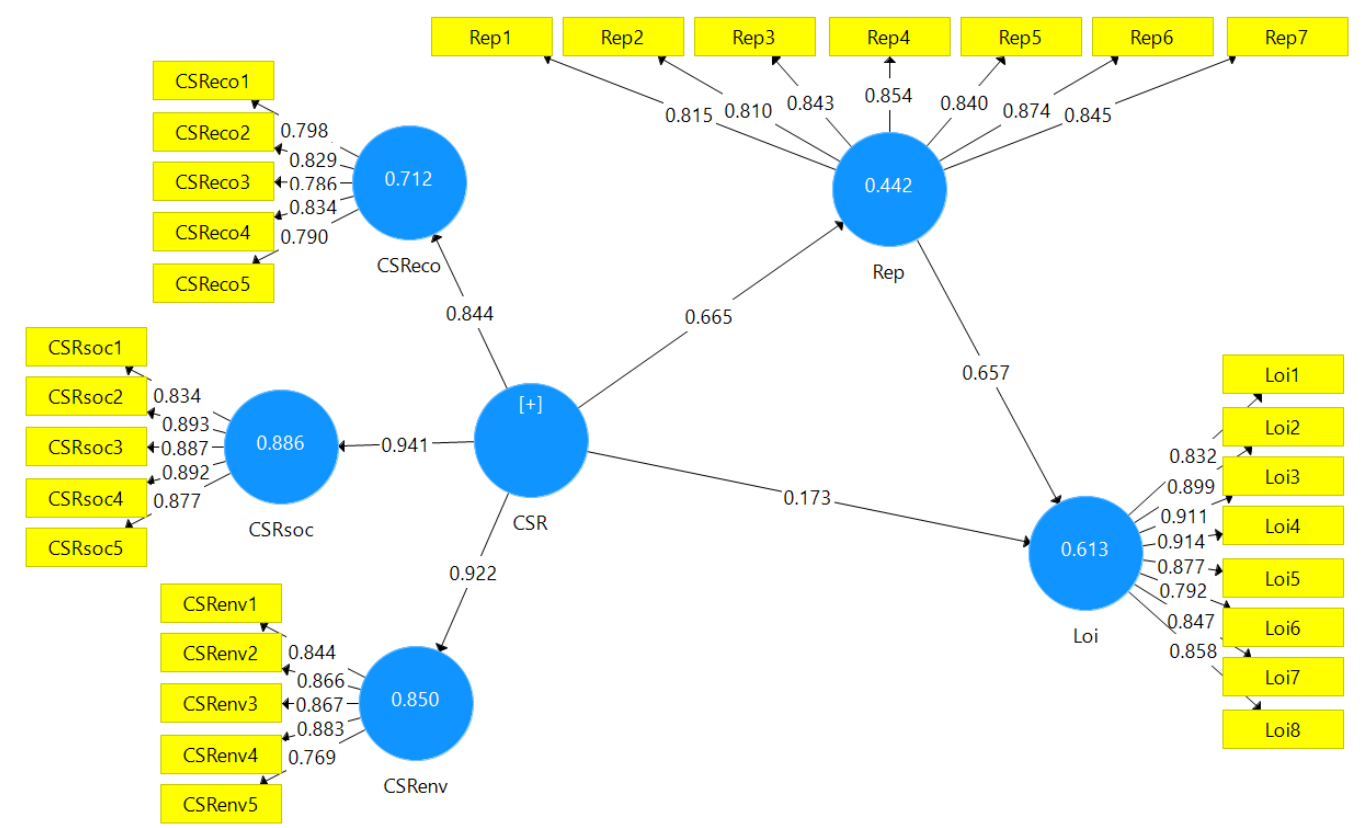

FIGURE 1. STRUCTURAL MODEL

Source: Authors with SmartPLS (v3.3.2) (Ringle, Wende, \& Becker, SmartPLS (v 3.3.2), 2015)

The $R^{2}$ values indicate that the CSR explain $44.2 \%$ of the variance in corporate reputation $\left(R_{R e p}^{2}=\right.$ $0.442)$ and CSR together with corporate reputation $61.3 \%$ in customer loyalty $\left(R_{L o i}^{2}=0.613\right)$. 


\section{Testing the research hypotheses}

To evaluate the research hypotheses, the standardized path coefficients' values and significance and associated bias corrected intervals was obtained by the bootstrapping procedure with 5000 re-samples. The results for the direct and indirect effects, alongside with the effects size and decisions on the research hypotheses are reported in table 4 . According to the results, all relationships in the model are statistically significant $(p<0.001)$. CSR has a positive impact on customer loyalty $(\beta=0.173, t=3.385, p<0.001)$. CSR also positively influences the company's reputation $(\beta=0.665, t=21.462, p<0.001)$, and corporate reputation positively influences customer loyalty $(\beta=0.657, t=14.626, p<0.001)$. Therefore, the first hypotheses $(\mathrm{H} 1, \mathrm{H} 2$ and $\mathrm{H} 3)$ are confirmed.

TABLE 4. HYPOTHESES TESTING (DIRECT AND INDIRECT EFFECTS)

\begin{tabular}{|c|c|c|c|c|c|c|c|c|}
\hline \multirow{2}{*}{ Hypotheses } & \multirow{2}{*}{ Relationships } & \multirow{2}{*}{$\beta$} & \multirow{2}{*}{ SE } & \multirow{2}{*}{$t$} & \multicolumn{2}{|c|}{$95 \% \mathrm{BCl}$} & \multirow{2}{*}{ Decision } & \multirow{2}{*}{$f^{2}$} \\
\hline & & & & & LL & UL & & \\
\hline \multicolumn{9}{|c|}{ Direct effects } \\
\hline$\overline{\mathrm{H} 1(+)}$ & CSR -> Loi & 0.173 & 0.051 & $3.385^{\star \star \star}$ & 0.074 & 0.274 & Supported & 0.043 \\
\hline $\mathrm{H} 2(+)$ & CSR $->$ Rep & 0.665 & 0.031 & $21.462^{\star * \star}$ & 0.599 & 0.722 & Supported & $0.794^{* \star \star}$ \\
\hline $\mathrm{H} 3(+)$ & Rep -> Loi & 0.657 & 0.045 & $14.623^{* * *}$ & 0.563 & 0.739 & Supported & $0.621^{* * *}$ \\
\hline \multicolumn{9}{|c|}{ Indirect effect } \\
\hline $\mathrm{H} 4$ & CSR $->$ Rep $->$ Loi & 0.437 & 0.035 & $12.553^{* * *}$ & 0.370 & 0.437 & Supported & - \\
\hline
\end{tabular}

$\beta=$ standardized path coefficients. $S E=$ standard errors. $\mathrm{BCl}=$ bias corrected confidence intervals. $f^{2}=$ effect size. ${ }^{* * *} p<0.001$. Source: Authors with SmartPLS (v3.3.2) (Ringle, Wende, \& Becker, 2015).

To test the mediating effect of corporate reputation on the relationship between CSR and customer loyalty, a bootstrapping technique with 5000 re-sampling was used. The indirect effect of CSR on customer loyalty is statistically significant $(\beta=0.437, t=12.553,95 \% \mathrm{BCl}[0.370,0.437])$. Therefore, the corporate reputation has the role of mediator on the relationship between CSR and loyalty and the $\mathrm{H} 4$ hypothesis is confirmed. Because both the direct and the indirect effect are statistically significant and have the same sign, may be concluded that there is a complementary partial mediation relationship. (Cepeda Carrión, Nitzl., \& Roldán, 2017). All formulated hypotheses were validated.

Moreover, analyzing the effect size $\left(f^{2}\right)$ may be notted that CSR has a strong effect on corporate reputation $\left(f_{C S R \rightarrow R e p}^{2}=0.794, p<0.001\right)$, as well as corporate reputation on customer loyalty $\left(f_{R e p->\text { Loi }}^{2}=0.794, p<0.001\right)$, while CSR has no significant effect on customer loyalty $\left(f_{C S R \rightarrow \text { Loi }}^{2}=0.621, n s\right)$.

These results confirm previous studies that indicate the existence of a positive relationship between CSR and loyalty (Du, Bhattacharya, \& Sen, 2010; Martinez \& del Bosque, 2013; Moisescu O. I., 2017; Pratihari \& Uzma, 2018; Perez \& del Bosque, 2015; Cuesta-Valiño, Rodríguez, \& Núñez-Barriopedro, 
2019). Also, the mediation model is validated, obtaining results similar to those in the study of Gurlek, Düzgün, \& Meydan Uygur (2017), who researches this mediation model for the hotel industry in Turkey.

\section{DISCUSSIONS AND IMPLICATIONS}

The results obtained show that CSR positively influences both the corporate reputation and customer loyalty. Also, the confirmation of the mediating role of the corporate reputation highlights the way in which the effects that CSR determines are transmitted on customer loyalty. Thus, reputation enhances this relationship. The mediation model aims to highlight the process that underlies the relationship between CSR and customer loyalty.

The results of this research underline the importance of adopting responsible business practices and policies in the field of retail trade in Romania if customer loyalty is desired. But in order to maximize this relationship, it is necessary for the effect of CSR to be transmitted on customer loyalty through corporate reputation, this fact being demonstrated by testing the mediation model. Therefore, the improvement of the corporate reputation has the role of increasing the effect that CSR has on the customer loyalty process. This aspect highlights the need to promote CSR actions in the public space in order to increase their level of perception among customers. Only when the CSR activity of a company is known by customers, the positive effects are maximum. In order for the promotion to be effective, it must be done on several communication channels: social networks, mass media, the company's website, street advertising, etc.

The implications of these results are relevant to both theorists and practitioners. This paper enriches the literature focus on the relationship between CSR and customer loyalty in Romania by analyzing the mediating role of corporate reputation. This model of mediation has not been previously addressed for Romanian retail. Thus, the premises for future research are established to deepen the mediation model tested in this paper.

Regarding the usefulness for practitioners, in this category falling the managers of retail companies, this refers to the emphasis on the integration of CSR in the retail companies' core strategy. Although the benefits of CSR implementation are wildly recognized, the results of this research highlight the usefulness of CSR practices in achieving a major goal of the retail companies, determining customer loyalty.

This paper emphasizes the interest that Romanian clients attach to CSR, each of the three dimensions having a high level of perception. Managers need to take this into account and understand the customers' expectations in terms of the ethical and moral character of their companies, in order to implement the most desired CSR practices. Moreover, managers should also be aware of the importance of communicating CSR practices and policies, thus improving company's reputation, since customers tend to be more loyal to 
companies with a positive image. In order for the promotion to be effective, it must be done on several communication channels: social networks, mass media, the company's website, street advertising, etc. Efficient communication of CSR practices will help to highlight the unique characteristics of the company, creating the premises for obtaining a competitive advantage.

\section{CONCLUSIONS}

CSR is a particularly important element of today's business environment. This is due to the many studies that research and confirm the many benefits that CSR can generate for the company. The importance given to CSR is also manifested on the Romanian market, where companies in the field of retail trade are actively involved in carrying out social or environmental activities. For these companies, the creation of loyal customers is a strategic objective that allows obtaining a competitive advantage over competing companies. Also, improving the corporate reputation will result in numerous benefits for the company.

Since the results obtained validated both the positive influence that CSR has on both customer loyalty and corporate reputation, but also the mediating role that corporate reputation has on this relationship, we can say that CSR is a strategic weapon with which companies can achieve financial performance and sustainable development. The benefits of CSR are also reflected in employees, people from disadvantaged groups, local communities, or society as a whole. This creates a "win-win" situation in which all parties have something to gain. Therefore, the adoption of CSR is a desirable practice for any company, contributing to the success of the company, but also to the general good of society.

The main limitation of the research is the sample structure, mostly determined by the questionnaire distribution in online environment. If this aspect is remedied, future research may investigate the differences in the relationship between CSR, corporate reputation, and customer loyalty, depending on different retailers' and customers characteristics. Despite the mentioned limitation, this paper provides new insides on CSR and its potential benefits in Romanian retail, contributing to the promotion of CSR practices and policies.

\section{REFERENCES}

Aaker, D. A. (1991). Managing Brand Equity: Capitalizing on the Value of a Brand Name,. New York: The Free Press.

Aaker, D. A. (1996). Measuring brand equity across products and markets. California Management Review, 38(3), 103-120.

Anca, C., Aston, J., Stanciu, E., \& Rusu, D. (2011). Responsibilitate Socială (Corporativă) în România. Analiză situaţională şi recenzie a practicilor actuale. București. 
Bălan, B. A., \& Burlea-Șchiopoiu, A. (2017). The development of a corporate reputation metric: A customer perspective. In F. Pînzaru, A. Zbuchea, C. Brătianu, E. M. Vătămănescu, \& A. Mitan (Eds.), Major challenges of oday's economy (pp. 595-606). Bucharest: Tritonic.

Bhattacharya, C., \& Sen, S. (2004). Doing Better at Doing Good: When, Why, and How Consumers Respond to Corporate Social Initiatives. California Management Review, 47(1), 9-24. doi:10.2307/41166284

Bhattacharya, C., Korschun, D., \& Sen, S. (2009). Strengthening Stakeholder-Company Relationships Through Mutually Beneficial Corporate Social Responsibility Initiatives. Journal of Business Ethics, 85, 257-272. doi:10.1007/s10551-008-9730-3

Burlea Șchiopoiu, A., \& Popa, I. (2013). Legitimacy Theory. In S. O. Idowu, N. Capaldi, L. Zu, \& A. D. Gupta (Eds.), Encyclopedia of Corporate Social Responsibility. Heidelberg, Berlin: Springer. doi:10.1007/978-3-642-28036-8_471

Carroll, A. (1991). The Pyramid of Corporate Social Responsability: Toward the Moral Management of Organizational Stakeholders. Business Horizon, 34(4), 39-48. doi:10.1016/00076813(91)90005-G

Cepeda Carrión, G., Nitzl., C., \& Roldán, J. I. (2017). Mediation Analyses in Partial Least Squares Structural Equation Modeling: Guidelines and Empirical Examples. In H. Latan, \& R. Noonan (Eds.), Partial Least Squares Path Modeling (pp. 173-197). Cham: Springer. doi:10.1007/978-3319-64069-3_8

Chin, W. W. (1998). The partial least squares approach for structural equation modeling. In G. A. Marcoulides (Ed.), Methodology for business and management. Modern methods for business research (pp. 295-336). Mahwah, NJ: Lawrence Erlbaum Associates.

Cuesta-Valiño, P., Rodríguez, P. G., \& Núñez-Barriopedro, E. (2019). The impact of corporate social responsibility on customer loyalty in hypermarkets: A new socially responsible strategy. Corporate Social Responsibility and Environmental Management, 26(3), 1-9. doi:10.1002/csr. 1718

Du, S., Bhattacharya, C., \& Sen, S. (2010). Maximizing Business Returns to Corporate Social Responsibility (CSR): The Role of CSR Communication. International Journal of Management Reviews, 12(1), 8-19. doi:10.1111/j.1468-2370.2009.00276.x

Dunn, R., \& Wrigley, N. (1984). Store Loyalty for Grocery Products: An Empirical Study. Area, 16(4), $307-$ 314.

East, R., Harris, P., Willson, G., \& Lomax, W. (1995). Loyalty to supermarkets. The International Review of Retail, Distribution and Consumer Research, 5(1), 99-109. doi:10.1080/09593969500000006

Gardberg, N., \& Fombrun, C. (2002). The Global Reputation Quotient Project: First Steps Towards a Cross-Nationally Valid Measure of Corporate Reputation. Corporate Reputation Review, 4(4), 303-307. doi:10.1057/palgrave.crr.1540151

Graafland, J. J., Eijffinger, S., \& Smid, H. (2004). Benchmarking of Corporate Social Responsibility: Methodological Problems and Robustness. Journal of Business Ethics, 53, 137-152. doi:10.1023/B:BUSI.0000039404.67854.e1

Gurlek, M., Düzgün, E., \& Meydan Uygur, S. (2017). How does corporate social responsibility create customer loyalty? The role of corporate image. Social Responsibility Journal, 13(3), 409-427. doi:10.1108/SRJ-10-2016-0177 


\section{Nae, N., Ștefan, S.C., Albu, C.F. \\ CORPORATE SOCIAL RESPONSIBILITY'S PATHWAYS TOWARDS CUSTOMER LOYALTY IN ROMANIAN RETAIL: A PLS-SEM MEDIATION ANALYSIS}

Hair, J. F., Sarstedt, M., Ringle, C. M., \& Guderga, S. F. (2018). Advanced Issues in Partial Least Squares Structural Equation Modeling (PLS-SEM). Thousand Oaks, CA: Sage.

Hair., J. F., Hult, G. T., Ringle, C. M., \& Sarstedt, M. (2017). A primer on partial least squares structural equation modeling (PLS-SEM) (2nd ed.). Thousand Oaks: SAGE.

Helm, S. (2007). One reputation or many? Comparing stakeholders' perceptions of corporate reputation. Corporate Communications: An International Journal, 12(3), 238-254.

Henseler, J., Ringle, C. M., \& Sarstedt, M. (2015). A new criterion for assessing discriminant validity in variance-based structural equation modeling. Journal of the Academy of Marketing Science, 43(1), 115-135. doi:10.1007/s11747-014-0403-8

Hristea, A. M. (2011). Corporate Social Responsibility - between Desideratum and Reality . Theoretical and Applied Economics, 18(10), 57-74.

lamandi, I. E., \& Filip, R. (2008). Etică și responsabilitate socială corporativă în afacerile internaționale. București: Editura Economică.

IBM Corp. (2019). IBM SPSS Statistics for Windows, Version 26.0. Armonk, NY: IBM Corp.

Irina, I., \& Zaiț, A. (2016). Reputaţie corporată, satisfacţie şi loialitate -analiză a posibilelor legături cauzale. Revista Română de Marketing, 11(2), 36-46.

Majumdar, A. (2005). A Model for Customer Loyalty for Retail Stores inside Shopping Malls- An Indian Perspective. Journal of Services Research(Special Issue (December)), 47-64.

Martinez , P., Perez, A., \& del Bosque, I. R. (2014). CSR influence on hotel brand image and loyalty. Academia Revista Latinoamericana de Administración, 27(2), 267-283. doi:10.1108/ARLA-122013-0190

Martinez, P., \& del Bosque, I. R. (2013). CSR and customer loyalty: The roles of trust, customer identification. International Journal of Hospitality Management, 35(1), 89-99.

Matten, D., \& Moon, J. (2008). "Implicit" and "Explicit" CSR: A Conceptual Framework for a Comparative Understanding of Corporate Social Responsibility. The Academy of Management Review, 33(2), 404-424.

Mihalache, S.-Ș. (2015). Studiu privind percepția consumatorilor români cu privire la responsabilitatea socială corporativă. Universitatea Babeș- Bolyai Cluj-Napoca. Cluj-Napoca: Școala doctorală Științe Economice și Gestiunea Afacerilor.

Moisescu, O. I. (2015). Responsabilitatea socială corporativă și loialitatea clienților . București: Editura ASE.

Moisescu, O. I. (2017). From CSR to Customer Loyalty: An Empirical Investigation in the Retail Banking Industry of a Developing Country. Scientific Annals of Economics and Business, 64(3), 307-323. doi:10.1515/saeb-2017-0020

Moisescu, O., \& Berács, J. (2015). Explorarea efectului RSC percepute asupra loialităţii clienţilor pe piaţa produselor lactate. Romanian Journal of Marketing, 10(2), 38-53.

Perez, A., \& del Bosque, I. R. (2015). Corporate social responsibility and customer loyalty: exploring the role of identification, satisfaction and type of company. Journal of Services Marketing, 29(1), 1525. doi:10.1108/JSM-10-2013-0272

Pop, N. A., \& Dabija, D. C. (2014). Influenta responsabilitatii sociale a corporatiei asupra loalitatii cumparatorilor în comertul de detail. Romanian Journal of Marketing(4), 11-32. 
Nae, N., Ștefan, S.C., Albu, C.F.

CORPORATE SOCIAL RESPONSIBILITY'S PATHWAYS TOWARDS CUSTOMER LOYALTY IN ROMANIAN RETAIL:

A PLS-SEM MEDIATION ANALYSIS

Pratihari, S. K., \& Uzma, S. H. (2018). CSR and corporate branding effect on brand loyalty: a study on Indian banking industry. Journal of Product \& Brand Management, 27(1), 57-78. doi:10.1108/JPBM-05-2016-1194

Ramasamy, B., Yeung, M., \& Au, A. (2010). Consumer support for corporate social responsibility (CSR): The role of religion and value. Journal of Business Ethics, 91, 61-72. doi:10.1007/s10551-0100568-0

Ringle, C. M., Sarstedt, M., Mitchell, R., \& Gudergan, S. P. (2018). Partial least squares structural equation modeling in HRM research. The International Journal of Human Resource Management, 31(12), 1617-1643. doi:10.1080/09585192.2017.1416655

Ringle, C. M., Wende, S., \& Becker, J. M. (2015). SmartPLS (v 3.3.2). Bönningstedt: SmartPLS GmbH. Retrieved August 10, 2020, from https://www.smartpls.com

Simionescu, L. N. (2018). Responsabilitatea socială şi performanţa financiară a companiilor. Bucureşti: Editura ASE.

Stancu, A. (2018). Marketing şi responsabilitate socială: o abordare strategicăprivind compania sustenabilă. București: Editura ASE.

Tsoutsoura, M. (2004). Corporate Social Responsibility and Financial Performance. Berkeley: UC Berkeley: Center for Responsible Business.

Vashchenko, M. (2014). Organizational CSR Portfolio. Business and Professional Ethics Journal, 33(4), 351-369. doi:10.5840/bpej201512319

Wold, H. (1982). Soft Modeling: The Basic Design and Some Extensions. In K. G. Jöreskog, \& H. O. Wold (Eds.), Systems Under Indirect Observations: causality, structure, prediction (pp. 1-54). Amsterdam: North-Holland. 